\section{Barriers, Adaptability, Employability, and Satisfaction: Career Perceptions of Business Students}

\author{
Barreiras, Adaptabilidade, Empregabilidade e Satisfação: Percepções de \\ Carreira de Formandos em Administração
}

\author{
Mariana Ramos de Melo*1 0 \\ Priscilla de Oliveira Martins-Silva ${ }^{10}$ \\ Alexsandro Luiz de Andrade ${ }^{2}$ \\ Ralf Luis de Moura ${ }^{10}$
}

\section{ABSTRACT}

Objective: this study was aimed to verify how perceptions of career barriers and adaptability held by senior undergraduate students attending Business Administration programs influence employability and career satisfaction. Method: a survey was conducted among 358 senior undergraduate students. Data analysis included descriptive statistics, hypothesis tests for differences between means, and structural equation modeling. Results: significant differences were found in individuals' perceptions regarding career barriers depending on sex and race. Contrary to the expected, the hypothesis test showed that contextual career barriers do not predict employability or satisfaction. Adaptability, in turn, predicted both, while employability predicted satisfaction. Conclusions: the results reinforce that sociodemographic characteristics are potential indicators to support understanding of perceived career barriers. Additionally, the students' continued development of adaptability (concern, control, curiosity, confidence) to advance their careers and life plays an important role, positively influencing perceptions of overall abilities for work (employability) and career success.

Keywords: career development; career barriers; adaptability; career success; higher education.
* Corresponding Author.

1. Universidade Federal do Espirito Santo, Programa de Pós-Graduação em Administração, Vitória, ES, Brazil 2. Universidade Federal do Espírito Santo, Programa de Pós-Graduação em Psicologia, Vitória, ES, Brazil.

Cite as: Melo, M. R. de, Martins-Silva, P. de O., Andrade, A. L. de, \& Moura, R. L. de. (2021). Barriers, adaptability, employability, and satisfaction: Career perceptions of Business students. Revista de Administração Contemporânea 25(6), e 190124. https://doi.org/10.1590/1982-7849rac2021190124.en

\section{RESUMO}

Objetivo: esta pesquisa pretende verificar a influência das percepçôes de barreiras de carreira e de adaptabilidade na empregabilidade e na satisfação com a carreira entre formandos em Administração em instituiçóes de educação superior. Métodos: realizou-se uma pesquisa do tipo survey com 358 estudantes dos últimos semestres da graduação. A análise dos dados envolveu estatística descritiva, teste de hipótese da diferença entre médias amostrais e modelagem de equaçóes estruturais. Resultados: houve diferenças significativas nas percepções de barreiras de carreira conforme o sexo e a cor. No teste das hipóteses, constatou-se que barreiras contextuais de carreira não predizem a empregabilidade e a satisfaçáo, ao contrário do que era esperado. Já a adaptabilidade se revelou como preditora de ambas, e a empregabilidade se revelou como preditora da satisfação. Conclusóes: os resultados reforçam que as características sociodemográficas dos indivíduos são indicadores potenciais para a compreensáo das percepçóes de barreiras de carreira. Ademais, o desenvolvimento contínuo pelos estudantes da adaptabilidade (preocupação, controle, curiosidade, confiança) para construir as carreiras e a própria vida influencia de forma importante as percepçóes favoráveis de capacidades gerais para o trabalho (empregabilidade) e de sucesso na carreira.

Palavras-chave: desenvolvimento de carreira; barreiras de carreira; adaptabilidade; sucesso de carreira; educação superior.

\begin{tabular}{|c|c|c|c|c|c|c|c|c|c|}
\hline & 1 & 2 & 3 & 4 & 5 & 6 & 7 & 8 & 9 \\
\hline $1^{\text {st }}$ round & (x) & $\stackrel{\varphi}{2}$ & (x) & (x) & (x) & $\stackrel{\theta}{2}$ & & & \\
\hline $2^{\text {nd }}$ round & 2 & & & & & & & & \\
\hline $3^{\text {rd }}$ round & 2 & & & & & & & & \\
\hline
\end{tabular}

JEL Code: O15, A2, J28. Editor-in-chief: Wesley Mendes-da-Silva (Fundação Getulio Vargas, EAESP, Brazill) Reviewers: Christine Schröeder (Universidade Federal do Rio Grande do Sul, EA, Brazil) Ana Paula Moreno Pinho (Universidade Federal do Ceará, Brazil) (] Peer Review Report: The Peer Review Report is available at this external URL. Received: March 25, 2019 Last version received: February 02, 2021 Accepted: February 03,2021 


\section{INTRODUCTION}

People in general deal with career-related issues throughout life. These issues are relevant and addressed by the academic literature, mainly because increasingly contextualized meanings are assigned to this subject. These matters impact professionals from the most varied fields and organizations alike, considering the influence of careers on essential aspects of people's lives, such as professional performance, health, and well-being (Magalhães \& Bendassolli, 2013). In this postmodern era, career theories emphasize a career management perspective associated with life management (Di Fabio, 2019). In practical terms, career guidance's primary purpose is to ensure that individuals' career satisfaction is maximized throughout life (Perera \& Athanasou, 2019).

In this sense, career development is related to various transformations that affect the corporate world. Academia has addressed re-significations of the bond existing between individuals and work. Among the numerous transformations, there is a growing concern with employability (Perera \& Athanasou, 2019), reflexivity (Perera \& Athanasou, 2019; Savickas, 2016), the instability of employment relationships (Di Fabio, 2019), the increase in informal jobs, rapid digital transformations, and automated processes (Perera \& Athanasou, 2019).

Individuals tend to experience greater instability and insecurity in a fluid and flexible work context (Di Fabio, 2019). The current Brazilian job market and recent economic and financial crises (Barbosa Filho, 2017; Instituto Brasileiro de Geografia e Estatística [IBGE], 2020; Oreiro, 2017) may significantly influence personal perceptions toward career management. Individual beliefs become increasingly relevant in a career context, and self-management behavior and characteristics are increasingly demanded from individuals in the current context of the 21st century (Di Fabio, 2019; Lent \& Brown, 2013).

Perceived career barriers (Swanson, Daniels, \& Tokar, 1996) are part of current transformations and turbulences. In the career and job context, changes caused by the transition from an industrial society based on manufacturing systems to a knowledge-based society require new skills and resources from professionals, including adaptability (Savickas, 2013). Hence, the ability to continually adjust and adapt amidst uninterrupted economic, social, and technological development is desirable - and even mandatory (Johnston, 2016).

According to Dahling, Melloy and Thompson (2013), most of the studies addressing perceived career barriers emphasize barriers at an individual level, that is, barriers an individual perceives within him/herself. This study, in turn, emphasizes contextual perceived barriers. Another gap in the literature addressed in this study is adaptability. Johnston (2016) states that there is an opportunity to investigate career adaptability in the population experiencing transitions, or according to the theory, mini-cycles (Savickas, 2013). These moments in life are marked by certain career destabilization, and for this reason, individuals are required to plan, explore, and manage skills more intensively (Johnston, 2016; Savickas, 2013), skills inherent to career adaptability.

Considering the previous discussion, this study addresses the individual perceptions of senior undergraduate students attending a Business Administration program. A theoretical model based on Career Barriers (contextual) and Career Adaptability is suggested to address the gaps mentioned earlier. The purpose is to investigate these constructs' impact on perceptions regarding career outcomes, i.e., Employability and Satisfaction. The hypotheses are established according to theoretical and empirical assumptions. Note that the study of perceptions of career outcomes is relevant not only for organizations but also for individuals, especially in terms of career development and self-management.

Therefore, the following objective was established: to verify the influence of perceived career barriers and adaptability on employability and job satisfaction among senior undergraduate students attending a Business Administration program. A non-probabilistic sample was adopted in this survey (Cozby, 2003), and descriptive statistics and multivariate analyses (Hair, Black, Babin, Anderson, \& Tatham, 2009) were used to verify associations between constructs.

This study's relevance and originality are supported by the following: (a) it contributes to the still incipient development of studies addressing career in Brazil; (b) career is investigated from an individual perspective, based on the career barriers theory (Swanson et al., 1996) - grounded on social cognitive carrier theory proposed by Lent, Brown and Hackett (1994) — and career adaptability, addressed in the career construction theory proposed by Savickas (2013); (c) perceived career barriers and adaptability, employability, and job satisfaction are studied together, supporting a greater understanding of the phenomenon and studies addressing these theoretical concepts; and (d) it broadens explanations regarding this phenomenon considering a turbulent context, permeated of concerns and apprehension arising from the social and economic aspects of the job market.

Finally, by disclosing these senior undergraduate students' perceptions, this study is expected to 
contribute with innovative and specific strategies to positively influence the cognitive aspects of individuals during educational training. Additionally, aspects such as diversity are portrayed in a career context, possibly contributing to a critical reflection of the Brazilian job market's structural heterogeneity, the actions of higher education institutions directed to students, and in general, current and collective thinking regarding careerrelated issues.

\section{THEORETICAL FRAMEWORK}

\section{Career}

Over the years, the world of work and organizations have experienced numerous changes in their operations, and for this reason, the role of individuals in career development has become evident. The unpredictable nature of careers requires that individuals adopt non-traditional career success standards and become concerned with experiences that can promote learning and adaptability (Vianen, Pater, \& Preenen, 2019). In this sense, new possibilities are identified for people to advance their careers.

Therefore, the conception of technical-scientific careers (associated with ascendance in a hierarchical structure and promotions) is no longer appropriate, considering that it does not always value qualities such as initiative, creativity, or reflexivity (Pinho, Kilimnik, \& Andrade, 2015). The most recent and integrative definition of career - coherent with transformations in which labor relations are included - involves the expectations, behaviors, cognitions, and feelings of people in a selfdevelopment process driven by life and work purposes (Magalhães \& Bendassolli, 2013). Therefore, a career can be defined as a multidimensional construct influenced by various factors (e.g., social, economic, psychological) and circumstances experienced throughout life (Magalhães \& Bendassolli, 2013).

\section{Current context of job market}

When considering the current context of the job market and career development in Brazil, it is essential to reflect upon some groups in this context of numerous particularities. Recent studies reinforce that the current Brazilian economic crisis reflects the government's loss of financial capacity, which influences and increases the number of informal jobs while the number of positions offered decreases (Barbosa Filho, 2017; Oreiro, 2017; Santos \& Gimenez, 2015). In addition to the Brazilian economic crisis, various transformations have affected the world of work, which also happens worldwide, such as the increased number of temporary and informal jobs, teleworking, and unemployment (Perera \& Athanasou, 2019). In this highly fluid, unpredictable, and transitional conjuncture, individuals are forced to deal with precarious jobs, and careers become characterized by change (Di Fabio, 2019).

In the third quarter of 2020, Brazil's unemployment rate was $14.6 \%$, i.e., equivalent to more than 14 million unemployed people (IBGE, 2020). These figures are even higher among the young population. The unemployment rate among 18- to 24-year-old individuals is higher than the national average in the same period (IBGE, 2020). Santos and Gimenez (2015) explain that, historically, young people compose the labor force segment of the highest social vulnerability. The characteristics of the Brazilian job market and the process in which young people are included in the job market result from the way economic development took place in Brazil, with high levels of regional, economic, and social inequality. Additionally, young individuals' participation in the Brazilian job market has been associated with labor exploitation, negatively affecting these individuals' education (Santos \& Gimenez, 2015).

Regarding characteristics such as the race of the Brazilian workforce, recent research indicates that Caucasian individuals, though they are not the largest group of the Brazilian population or workforce, comprise the largest percentage of the employed population, with $46.2 \%$, followed by mixed-race individuals (43.9\%), and Afro-Brazilians (8.9\%) (Instituto Brasileiro de Geografia e Estatística [IBGE], 2017). In 2020, unemployment affected the Afro-Brazilian and mixed-race population more intensively, $19.1 \%$ and $16.5 \%$, respectively. Both rates are above the national average, while unemployment among self-reported Caucasian individuals was $11.8 \%$ (IBGE, 2020).

Regarding sex, data from the third quarter of 2020 show that women (53.2\%) compose the largest group of people apt to work. However, the opposite is verified in this group in terms of employment. Significant differences were found between sexes; the employment rate of men $(57.3 \%)$ was ten percentage points above the national mean $(47.1 \%)$, while women's employment was ten percentage points below $(38.1 \%)$. Finally, differences were also found in terms of unemployment rates. In 2020 , unemployment among women $(16.8 \%)$ was above the national mean $(14.6 \%)$, while unemployment among men $(12.8 \%)$ was below the national mean (IBGE, 2020).

These data reveal the difficulties different groups of people face in the job market depending on their sociodemographic characteristics. 
Santos and Gimenez (2015) state that Brazil's socioeconomic development presents overly concentrated and exclusive characteristics, which are reflected in the statistics concerning the Brazilian job market. Thus, individual differences and diversity issues impact labor relations. In this sense, considering that Brazil's job market is structurally heterogeneous (Santos \& Gimenez, 2015), studies proposing a critical reflection upon these characteristics stand out due to the topic's relevance and urgency.

\section{Constructs and hypotheses}

The construct Career Barriers can be defined as any internal or external condition hindering an individual from advancing in his/her career. Internal barriers are those perceived in oneself, such as indecision or lack of confidence, while external barriers arise from the environment like one's country or city or the job market itself (Lent, Brown, \& Hackett, 2000; Swanson et al., 1996). The concept of career barriers originated in the 1970s when the particularities of women's career development were first investigated (Cardoso, 2009).

This study focuses on perceived external barriers. These barriers may be related to contextual aspects of varied aspects, such as the local economic context, information access, precarious labor contracts, restricted opportunities, or discrimination (Melo, Martins-Silva, \& Andrade, 2020). Recent studies report various barriers are perceived in the context, including contextual financial restrictions and a lack of job opportunities among college students (Urbanaviciute, Pociute, Kairys, \& Liniauskaite, 2016).

Empirical studies report differences between men's and women's career-related beliefs (Faria, Taveira, \& Saavedra, 2008; Lipshits-Braziler \& Tatar, 2012). Cardoso (2009) investigated young individuals and verified that women scored higher than men did in perceived career barriers. More recently, Silva (2016) performed invariance tests with different groups and found that men presented higher levels of positive career psychological aspects, while pessimist thoughts more frequently influenced women.

Studies addressing diversity aspects report differences in individuals' perceived external career barriers. Kim and O'Brien (2018) developed a study on barriers with different groups composed of female college students. The Afro-Brazilian groups, more frequently than Caucasian groups, reported career and educational barriers due to racial discrimination. The studies show that perceived career barriers differ according to individual characteristics such as sex and race (Lipshits-Braziler \& Tatar, 2012).

In this study, the focus on external barriers is based on the findings reported by Melo, Martins-Silva and Andrade (2020), using specific dimensions, namely: Lack of Support (perceived environmental barriers, such as a lack of vocational guidance services and restricted access to information); Ethnic Discrimination (racial discrimination); Sexual Discrimination (discrimination regarding one's biological sex/gender); and Restricted Opportunities (perceived difficulties regarding opportunities in the job market or a profession's general context). Hence, the first hypothesis is proposed:

H1 - The influence of perceived Career Barriers, regarding lack of support, discrimination, or restricted opportunities, differ according to sociodemographic variables, in which:

H1a - Women score higher than men; and

H1b - Afro-Brazilian or mixed-race people score higher than Caucasian individuals.

Perceptions concerning career outcomes, such as Employability, are also addressed in this study. Studies addressing employability gained force at the end of the 1990 s, when it was initially studied at an individual and organizational level, within various disciplines such as Business Administration and Psychology (Heijde \& Van Der Heijden, 2006). Recently, Employability has been addressed in the literature as a replacement for job stability, considering the latter has been changed given the current nature of employment contracts (Ladeira, Oliveira, Melo-Silva, \& Taveira, 2019).

Recent research defines employability as a phenomenon that involves psychological and social aspects and the continuous fulfilling, acquiring, or creating of work through the optimal use of competencies (De Vos, De Hauw, \& Van der Heijden, 2011; Heijde \& Van Der Heijden, 2006). Hence, perceived employability favors individuals' perception regarding their value for the job market and job satisfaction. In summary, employability is related to individual perceptions regarding career outcomes (Silva, 2016) and is increasingly more relevant in contemporaneous professional relations (Praskova, Creed, \& Hood, 2015).

Career Satisfaction, an outcome perception, is also part of the phenomenon addressed here. It is defined as an individual's perception of career success, considering objective and subjective aspects. The first refers to external factors such as hierarchical position, promotions, and salary. In turn, subjective aspects are based on an individual's psychological perspective toward his/her 
career and involve recognition, meaning, purpose, and prospects (Kuijpers, Schyns, \& Scheerens, 2006). Hence, one's career satisfaction is characterized as a unique individual assessment and is associated with elements that influence human behavior and perceptions.

Both employability and satisfaction can be considered perceptions regarding career outcomes. Therefore, based on an initial understanding of barriers, we assume that these perceptions influence employability and satisfaction. Silva and Andrade (2016) conducted a study on negative thoughts toward career and verified that these negatively correlate with perceived career outcomes. Hence, judgments seem to hinder an individual's professional life. Specifically, London (2014) explains that one's perception of career barriers negatively affects career satisfaction. Bullock-Yowell, Peterson, Reardon, Leierer and Reed (2011) state that negative thoughts toward one's career hinder perception of satisfaction toward both career and life in general. Hence, the following hypotheses are proposed:

H2 - Significant negative perceived Career Barriers predict perceived Employability; and

H3 - Significant negative perceived Career Barriers predict an individual's Career Satisfaction.

Finally, Adaptability is another construct addressed in this study. The term refers to an individual's ability to change and adapt to new circumstances without much difficulty. The ability to adapt to constant changes must remain throughout one's career at the expense of linear and predictable behavior. From this perspective, career adaptability is broadly defined as the ability to deal with predictable career planning tasks and unpredictable adjustments necessary throughout one's personal and professional life (Savickas, 1997).

Career adaptability is a multidimensional construct and includes four behavioral competencies: Concern (C), Control (CR), Curiosity (CS), and Confidence (CO). $\mathrm{C}$ refers to career planning and having a sense of career-related prospects. CR involves career development responsibility through pro-active behavior, facing adverse issues, and controlling one's career. CS refers to a behavior in which possibilities and scenarios are explored, having initiative, and searching for diversified experiences. CO refers to positive attitudes toward one's competencies, reflecting efforts to attain objectives and overcome obstacles (Savickas, 1997, 2013; Savickas \& Porfeli, 2012).

Silva (2016) found that beneficial aspects, such as adaptability, might significantly influence perceived career outcomes. The author explains that positive psychological characteristics (e.g., concern, control, among others) help individuals keep a positive career orientation, which favors the development of new skills to remain employed. Considering the context of transition between studies and work, Gamboa, Paixão and Palma (2014), found positive associations between career adaptability and perceive employability among college students. Ladeira, Oliveira, Melo-Silva and Taveira (2019) also found a significant and positive effect between career adaptability and perceived employability among senior undergraduates.

Studies addressing adaptability and satisfaction include Ambiel, Hernández and Martins (2016) which reports that satisfaction with the undergraduate program can reflect the students' adaptation process. From this perspective, one of the outcomes of career development is satisfaction itself (Savickas \& Porfeli, 2012). Hence, the fourth and fifth hypotheses are proposed:

H4 - Significant positive Adaptability predicts perceived Employability; and

H5 - Significant positive Adaptability predicts Career Satisfaction.

According to Lo Presti and Pluviano (2016), employability is a personal resource individuals develop over the course of their professional lives through valuable competencies and skills to increase career success. More recently, Vianen, Pater and Preenen (2019) verified that greater unpredictability in professional relations and the constant changes in the job market require individuals to assess their careers in terms of employability. The authors explain that employability perceptions can be promoted - for instance, in work environments and through challenging experiences - , and these are directly related to individual perceptions of career success. Based on the previous discussion, the last hypothesis is proposed:

H6 - Significant positive perceived Employability predicts Career Satisfaction.

The previous discussion and hypotheses resulted in the hypothetical structural model presented in Figure 1, which is discussed next. 


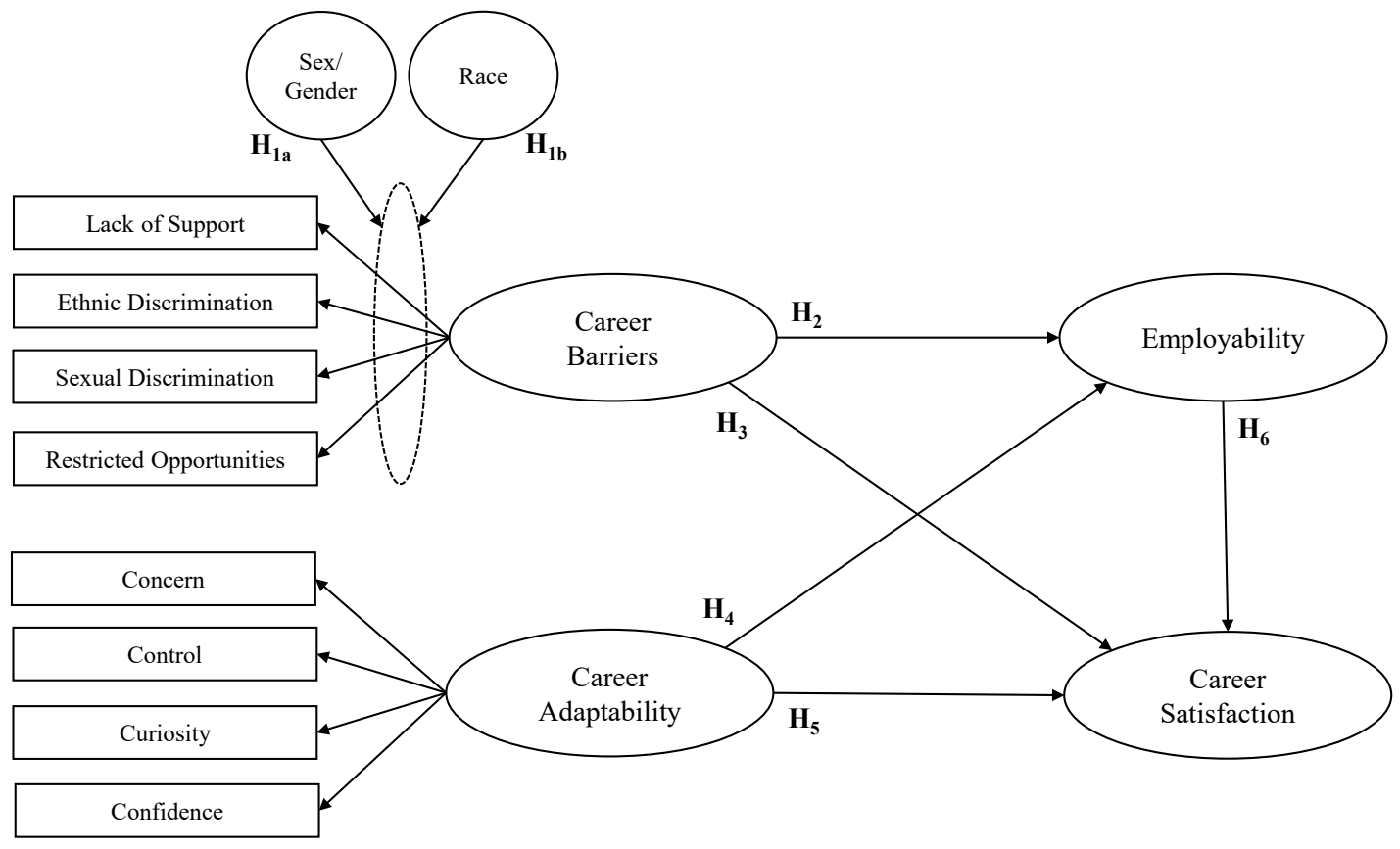

Figure 1. Hypothetical structural model.

Source: Developed by the authors. Structural model based on previous studies and proposed by this research.

\section{METHOD}

\section{Participants}

A total of 358 valid responses were obtained. The test power was calculated using $\mathrm{G}^{*}$ Power considering the post hoc analysis. The result, close to $100 \%$, was significant and satisfactory. Most participants were women $(\mathrm{N}=207 ; 57.8 \%)$, aged 27 on average $(\mathrm{SD}=6.03)$. Note that $78.3 \%(\mathrm{~N}=280)$ were between 19 and 30 years old. Most were single $(\mathrm{N}=248 ; 69.3 \%)$, Caucasian $(\mathrm{N}=155$; $43.3 \%)$, and of mixed race $(\mathrm{N}=150 ; 41.9 \%)$; only 49 individuals (13.7\%) self-reported being Afro-Brazilians. Most individuals had a paid job $(\mathrm{N}=305 ; 85.2 \%)$. Monthly family income was between $\mathrm{R} \$ 1,405.51$ and $\mathrm{R} \$ 4,216.50$ (44.4\%). Finally, regarding the participant HEIs, 254 (70.9\%) were private schools, with a prevalence of evening programs $(\mathrm{N}=315,88.0 \%)$.

\section{Study characterization and ethical aspects}

This is a correlational study using the survey method (Cozby, 2003). Note that the procedures were based on ethical criteria guiding research addressing human subjects, according to Resolution 466/12, Brazilian National Council of Health. The Institutional Review Board approved the study (Opinion Report No. 2,264,099).

\section{Data collection instruments}

These instruments were applied according to the following order: Career Barriers Perception Inventory (IPBC) (McDonald's omega [ $\omega$ ] from 0.81 to 0.86 ): developed by Cardoso (2009), adapted and summarized by Melo et al. (2020). It assesses the perception of barriers to career development that are external to 
individuals. Its 16 items are rated on a seven-point Likert scale and compose the following dimensions (with four items each): Ethnic Discrimination (ED) (e.g., being passed over for promotion due to racial discrimination); Sexual Discrimination (SD) (e.g., being sexually harassed at work); Lack of Support (LO) (e.g., having a precarious employment contract, working without a formal employment contract, temporary employment, or poorly defined jobs); and Restriction of Opportunities (RO) (e.g., not having opportunities to advance in the profession).

Career Adapt-Abilities Scale (CAAS) (Cronbach's alphas $[\alpha]$ from 0.83 to 0.89 ): developed by Savickas and Porfeli (2012) and adapted by Audibert and Teixeira (2015). It assesses the individuals' perceptions regarding skills developed to advance their careers and lives. It is a 24-item instrument rated on a five-point Likert scale. Six items compose each of its scales: Concern (e.g., thinking about what my future will be like); Control (e.g., keeping upbeat); Curiosity (e.g., exploring my surroundings); and Confidence (e.g., performing tasks efficiently).

Perceived Employability Scale (PES) $(\alpha=0.79)$ : developed by Silva (2016), it assesses general perceptions regarding the development of skills for work and attaining career goals. It is composed of eight items rated on a fivepoint Likert scale (e.g., do you think you will get a job that satisfies you in the future?).

Career Satisfaction Scale (CSS) $(\alpha=0.80)$ : developed by Greenhaus, Parasuraman and Wormley (1990) and adapted by Silva (2016), it assesses overall career satisfaction. It is composed of five items rated on a five-point Likert scale (e.g., I am satisfied with the success I have achieved in my career).

Sociodemographic Questionnaire: developed for this study, it addresses the participants' social and demographic characteristics (e.g., what is your age? Do you have a paid job?).

\section{Data collection and analysis}

Data were collected in a convenience sample (Cozby, 2003) composed of public and private HEIs located in the states of Espírito Santo and Minas Gerais, Brazil. Various HEIs were contacted, and seven authorized the survey and the collection of data in person. The students were collectively approached in the classrooms, and participation was voluntary.

Primary data were processed and analyzed using G*Power, version 3.1.9.2; Statistical Package for Social Sciences (SPSS), version 21; JAMOVI, version 0.8.1.5; and Analysis of Moment Structures (AMOS Graphics),
SPSS' extension. G*Power was initially used to verify the test power. Descriptive statistics were performed in the SPSS to characterize the students. This software was also used to test the statistical significance of differences between means (H1) (Hair et al., 2009).

Internal consistency was verified with JAMOVI, which was used to calculate McDonald's omega ( $\omega$ ) (Trizano-Hermosilla \& Alvarado, 2016), considered a robust measure to check the precision of research instruments (Dunn, Baguley, \& Brunsden, 2014). Using AMOS Graphics, multivariate analyses were performed with structural equation modeling (SEM) to verify the dependency hypotheses between the constructs ( $\mathrm{H} 2$ to H6) (Hair et al., 2009).

Adequacy of the structural model was verified according to the following: (1) $\chi^{2}$ normalization (simple ratio of $\chi^{2}$ to degrees of freedom: $\chi 2 /$ d.f.): optimal value below or equal $3 / 10$; acceptable up to $5 / 0$; (2) comparative fit index (CFI): above 0.90; (3) Tucker-Lewis index (TLI): above 0.90; and (4) root mean square error of approximation (RMSEA): optimal between 0.05 and 0.08 for $90 \%$ confidence interval; acceptable up to 0.10 (Hair et al., 2009). All the instruments were tested and analyzed according to psychometric methods to verify their validity and precision, considering the theoretical definition of the associated constructs and the sample at hand. For additional information, see Melo (2018) and Melo et al. (2020).

\section{RESULTS}

\section{Statistical description}

Descriptive statistics were verified for each of the instruments. Initially, the IPBC presented good reliability indexes in its four dimensions, with excellent McDonald's omega of the total scale $(\omega=0.93)$. The highest mean was obtained in the RO dimension (4.35; $\mathrm{SD}=1.43)$, while ED obtained the lowest mean $(3.54$; $\mathrm{SD}=1.80)$; the remaining scales obtained $\mathrm{LO}(4.07 ; \mathrm{SD}=1.54)$ and $\mathrm{SD}(3.85 ; \mathrm{SD}=1.72)$. The inventory's general mean was $3.95(\mathrm{SD}=1.41)$. The correlations between the IPBC's dimensions indicate from moderate to high positive significant associations. The $r$ values ranged from 0.61 to $0.81(p<0.01)$, and the highest correlation was found between SD and ED $(r=0.81 ; p<0.01)$. The lowest correlations were found between $\mathrm{LO}$ and ED and between $\mathrm{RO}$ and ED (both with $r=0.61 ; p<0.01$ ).

The CAAS' reliability indexes varied, $\mathrm{C}(\omega=0.83)$; CR $(\omega=0.75)$; CS $(\omega=0.84)$; and CO $(\omega=0.84)$, but showed good precision. The total scale obtained an index 
equal to 0.91, which is considered excellent. The CAAS' highest mean was found in the $\mathrm{CO}$ dimension (4.25; $\mathrm{SD}=0.59$ ), while the CS dimension obtained the lowest mean (3.85; $\mathrm{SD}=0.72$ ). The remained dimensions obtained similar means, $C(4.04 ; \mathrm{SD}=0.64)$ and $\mathrm{CR}$ $(4.05 ; \mathrm{SD}=0.59)$. The scale overall mean was 4.05 $(S D=0.51)$. The correlations between the dimensions indicated positive and significant associations, in which $r$ ranged between 0.35 and $0.63(p<0.01)$. The highest correlation was found between $\mathrm{CO}$ and CS $(r=0.63 ; p<0.01)$, while the lowest correlation was found between CR and C $(r=0.35 ; p<0.01)$.

Finally, PES and CSS presented good reliability indexes, $\omega=0.80$ and $\omega=0.88$ respectively. The PES' mean (3.94; $S D=0.56)$ was higher than the CSS' (3.16;
$\mathrm{SD}=0.84)$. Correlation between the scales indicated a positive and significant association, with $r=0.45(p<$ $0.01)$.

\section{Assessment of differences between groups $(\mathrm{H} 1)$}

A hypothesis test for differences between means was performed to verify the statistical significance of the different perceptions of career barriers held by the groups with other sociodemographic characteristics. As shown in Table 1 , the independent variables were sex $(\mathrm{H} 1 \mathrm{a})$ and race $(\mathrm{H} 1 \mathrm{~b})$. According to $\mathrm{G}^{*}$ Power, the minimum sample size was complied with; that is, at least 118 participants composed each group.

Table 1. Group difference test: sex and race.

\begin{tabular}{|c|c|c|c|c|c|c|c|}
\hline Instrument $\mid$ Dimensions & Sex | Race & Mean & $\begin{array}{l}\text { Standard } \\
\text { deviation }\end{array}$ & Error & Levene Test & $T$ & $\begin{array}{c}p \\
\text { Means test }\end{array}$ \\
\hline Career Barriers & $\begin{array}{c}\text { Men } \\
\text { Women }\end{array}$ & $\begin{array}{l}3.68 \\
4.13\end{array}$ & $\begin{array}{l}1.49 \\
1.32\end{array}$ & $\begin{array}{l}0.12 \\
0.09\end{array}$ & 0.02 & -2.93 & $0.00^{* *}$ \\
\hline Ethnic Discrimination (ED) & $\begin{array}{c}\text { Men } \\
\text { Women }\end{array}$ & $\begin{array}{l}3.34 \\
3.67\end{array}$ & $\begin{array}{l}1.86 \\
1.75\end{array}$ & $\begin{array}{l}0.15 \\
0.12\end{array}$ & 0.19 & -1.73 & 0.08 \\
\hline Sexual Discrimination (SD) & $\begin{array}{c}\text { Men } \\
\text { Women }\end{array}$ & $\begin{array}{l}3.33 \\
4.20\end{array}$ & $\begin{array}{l}1.77 \\
1.59\end{array}$ & $\begin{array}{l}0.15 \\
0.11\end{array}$ & 0.02 & -4.77 & $0.00^{* *}$ \\
\hline Lack of Support (LO) & $\begin{array}{c}\text { Men } \\
\text { Women }\end{array}$ & $\begin{array}{l}3.77 \\
4.27\end{array}$ & $\begin{array}{l}1.63 \\
1.44\end{array}$ & $\begin{array}{l}0.13 \\
0.10\end{array}$ & 0.01 & -2.99 & $0.00^{* *}$ \\
\hline Restriction of Opportunities (RO) & $\begin{array}{c}\text { Men } \\
\text { Women }\end{array}$ & $\begin{array}{l}4.30 \\
4.38\end{array}$ & $\begin{array}{l}1.46 \\
1.41\end{array}$ & $\begin{array}{l}0.12 \\
0.10\end{array}$ & 0.48 & -0.54 & 0.59 \\
\hline Career Barriers & $\begin{array}{l}\text { Caucasian } \\
\text { Mixed/Afro }\end{array}$ & $\begin{array}{l}3.75 \\
4.13\end{array}$ & $\begin{array}{l}1.40 \\
1.39\end{array}$ & $\begin{array}{l}0.11 \\
0.10\end{array}$ & 0.55 & -2.57 & $0.01^{* *}$ \\
\hline Ethnic Discrimination (ED) & $\begin{array}{l}\text { Caucasian } \\
\text { Mixed/Afro }\end{array}$ & $\begin{array}{l}3.23 \\
3.81\end{array}$ & $\begin{array}{l}1.82 \\
1.75\end{array}$ & $\begin{array}{l}0.15 \\
0.12\end{array}$ & 0.24 & -3.05 & $0.00^{* *}$ \\
\hline Sexual Discrimination (SD) & $\begin{array}{l}\text { Caucasian } \\
\text { Mixed/Afro }\end{array}$ & $\begin{array}{l}3.69 \\
4.01\end{array}$ & $\begin{array}{l}1.73 \\
1.69\end{array}$ & $\begin{array}{l}0.14 \\
0.12\end{array}$ & 0.81 & -1.73 & 0.08 \\
\hline Lack of Support (LO) & $\begin{array}{l}\text { Caucasian } \\
\text { Mixed/Afro }\end{array}$ & $\begin{array}{l}3.88 \\
4.24\end{array}$ & $\begin{array}{l}1.56 \\
1.51\end{array}$ & $\begin{array}{l}0.12 \\
0.11\end{array}$ & 0.66 & -2.19 & $0.03^{* *}$ \\
\hline Restriction of Opportunities (RO) & $\begin{array}{l}\text { Caucasian } \\
\text { Mixed/Afro }\end{array}$ & $\begin{array}{l}4.22 \\
4.48\end{array}$ & $\begin{array}{l}1.42 \\
1.42\end{array}$ & $\begin{array}{l}0.11 \\
0.10\end{array}$ & 0.83 & -1.77 & 0.08 \\
\hline
\end{tabular}

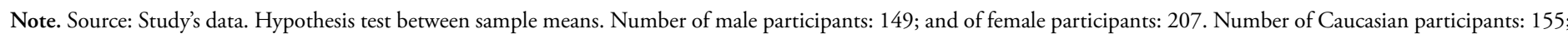
and of mixed-race or Afro-Brazilian individuals: 199.

In general, significant differences were found between men and women regarding perceived career barriers. Specifically, significant differences were found in the SD and $\mathrm{LO}$ dimensions. Hence, the test failed to reject $\mathrm{H} 1 \mathrm{a}$. As expected, significant differences were also found, in the overall scale and in the ED and LO dimensions, regarding perceived career barriers when the participants' race was taken into account; that is, the test failed to reject H1b. Note that two groups were considered in this analysis: one group composed of Caucasian individuals and one group composed of mixed-race and Afro-Brazilian individuals. 


\section{Assessment of the structural model ( $\mathrm{H} 2$ to $\mathrm{H} 6)$}

As shown in Figure 2, the structural equation model, represented by the measurement theory, was estimated to verify the hypotheses of association between the variables.

Goodness of fit indicated the model was satisfactory, according to the following: $[\chi 2=110.468 ;$ d.f. $=33$ $(p<0.001) ; \chi 2 /$ d.f. $=3.348$; CFI $=0.950 ;$ TLI $=0.932$; RMSEA $(90 \% \mathrm{CI})=0.081(0.065-0.098)]$. Career Barriers and Adaptability explained $40 \%$ of Employability. Career Satisfaction presented a coefficient of determination $\left(\mathrm{R}^{2}\right)$ of $21 \%$ and was explained by Career Barriers, Adaptability, and Employability. In Social Sciences, these effects are respectively considered large and moderate (Cohen, 1988). Table 2 shows the path coefficients to assess the structural model, with significant indicators of each dependency relationship.

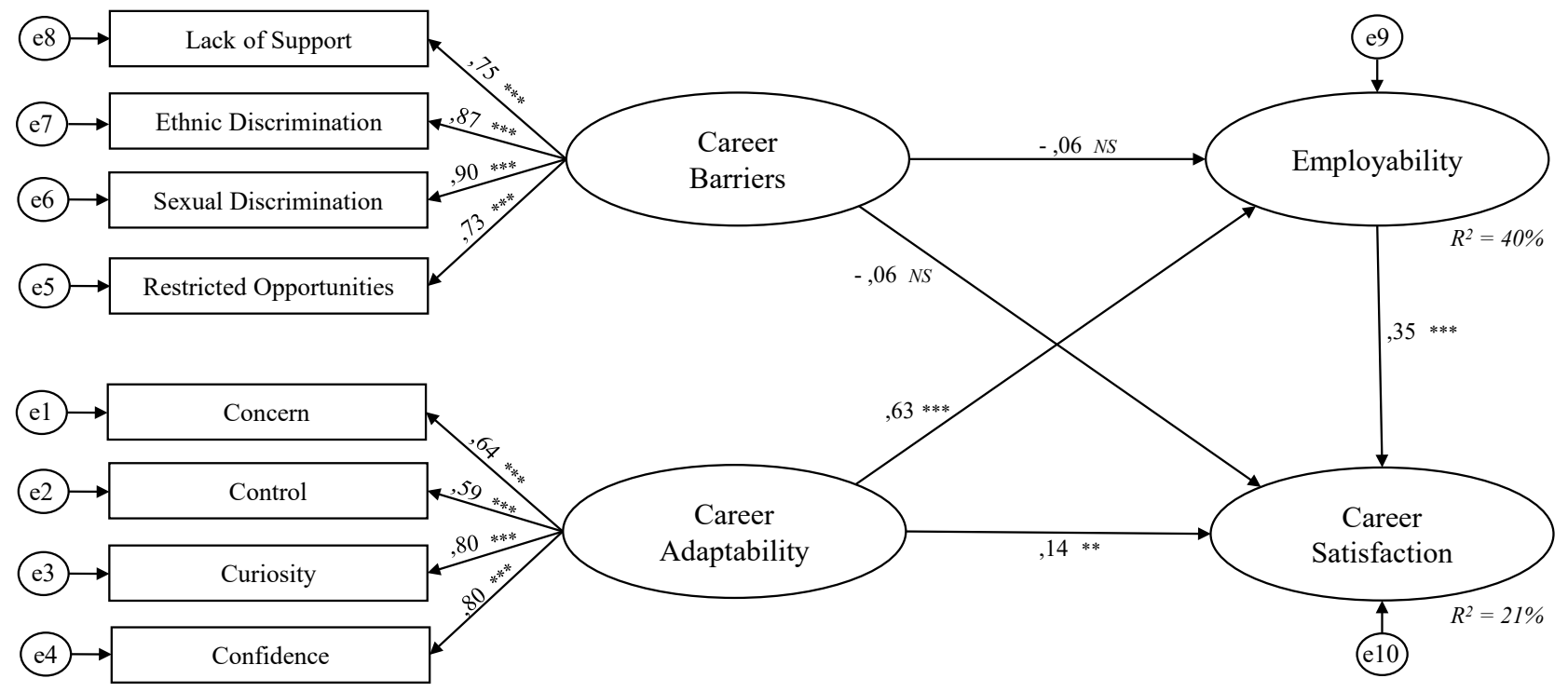

Figure 2. Structural model.

Source: Research data. Results of the hypothetical structural model test according to structural equation modeling.

Table 2. Standardized regression coefficients.

\begin{tabular}{|c|c|c|c|c|}
\hline Predictor Variable & & Dependent Variable & $\mathrm{B}$ & $p$ \\
\hline Career Barriers & $\rightarrow$ & Employability | H2 & -0.06 & 0.21 \\
\hline Career Barriers & $\rightarrow$ & Satisfaction $\mid \mathbf{H 3}$ & -0.06 & 0.22 \\
\hline Adaptability & $\rightarrow$ & Employability | H4 & 0.63 & $0.00^{* * *}$ \\
\hline Adaptability & $\rightarrow$ & Satisfaction $\mid \mathbf{H 5}$ & 0.14 & $0.04^{* *}$ \\
\hline Employability & $\rightarrow$ & Satisfaction $\mid \mathbf{H 6}$ & 0.35 & $0.00^{* * *}$ \\
\hline Career Barriers & $\rightarrow$ & Lack of Support & 0.75 & $0.00^{* * *}$ \\
\hline Career Barriers & $\rightarrow$ & Ethnic Discrimination & 0.87 & $0.00^{* * *}$ \\
\hline Career Barriers & $\rightarrow$ & Sexual Discrimination & 0.90 & $0.00^{* * *}$ \\
\hline Career Barriers & $\rightarrow$ & Restricted Opportunities & 0.73 & $0.00^{* * *}$ \\
\hline Adaptability & $\rightarrow$ & Concern & 0.64 & $0.00^{* * *}$ \\
\hline Adaptability & $\rightarrow$ & Control & 0.59 & $0.00^{* * *}$ \\
\hline Adaptability & $\rightarrow$ & Curiosity & 0.80 & $0.00^{* * *}$ \\
\hline Adaptability & $\rightarrow$ & Confidence & 0.80 & $0.00^{* * *}$ \\
\hline
\end{tabular}

Nota. Source: Research data. Structural equation modeling to test hypotheses (H2 to H6) and the significance of the dependency relationships between the predictor and dependent variables. 
Note that the coefficients of Career Barriers for Employability and Satisfaction were not significant. The structural relationships were significant for the remaining coefficients, ranging from 0.14 (Adaptability for Satisfaction) to 0.90 (Career Barriers for Sexual Discrimination). Therefore, when considering the theorized hypotheses, $\mathrm{H} 2$ and $\mathrm{H} 3$ are rejected, while the test failed to reject $\mathrm{H} 4, \mathrm{H} 5$, and $\mathrm{H} 6$.

\section{DISCUSSION}

\section{Exploratory aspects of the theoretical model}

The sample's sociodemographic profile reveals common characteristics among Brazilian college students, namely: young, single, and Caucasian. Other recent studies addressing college students also report this predominant profile (Instituto Nacional de Estudos e Pesquisas Educacionais Anísio Teixeira [Inep], 2017). Considering that the largest group attended evening programs $(88.0 \%)$, we expected that most would have a paid job, which was confirmed (85.2\%).

These results indicate the potential reasons why students prefer evening programs; that is, attending an evening program enables students to reconcile a paid work with studies. It reinforces what Ristoff (2016) found in his analyses: a typical 'working student' profile among Brazilian students attending Business Administration programs. This is a characteristic of students who work and support themselves, not requiring any help to finance their expenses. In fact, they often contribute to support (or support) their families.

Regarding the constructs addressed here, the highest mean was obtained in the RO dimension (4.35) from the inventory measuring perceived carrier barriers. The items in the inventory that most influenced the means were related to Brazil's economic instability, a situation that has endured for some years and results in a lack of opportunities to advance in the profession and difficulties in planning one's career. The results are in line with recent indicators reported by the Instituto Brasileiro de Geografia e Estatística (IBGE, 2020), Barbosa Filho (2017), and Oreiro (2017) regarding the Brazilian economic crisis. This crisis imposes considerable difficulties that need to be faced in the Brazilian job market, such as the high number of layoffs and decreased number of formal job positions.

Other factors that probably compounded this dimension refer to few opportunities for students to obtain educational training and limited knowledge concerning the world of work. These perceptions suggest that recent changes in the Brazilian job market impact students' perception, especially young students, making them more insecure and confused about their professional prospects. A total of $78.3 \%$ of the participants were between 19 and 30 years old. These findings are in line with the results reported by Santos and Gimenez (2015), who argue that the young population is currently the segment most intensively affected by the high level of unemployment in Brazil. Current indicators provided by IBGE (2020) reveal that, historically, the rate of unemployment among the young population reached its highest in recent years.

The dimensions that obtained the lowest means in terms of barriers perceptions (SD and ED) specifically refer to sexual and racial discrimination. However, it is essential to note that the ED mean was influenced by the sample's characteristics; most participants were Caucasians (43.3\%). Even though this dimension obtained the lowest score in the IPBC, it shows that ethnic discrimination is considered a barrier that hinders career development. Lipshits-Braziler and Tatar (2012) and Kim and O'Brien (2018) note that perceived carrier barriers differ according to the individuals' race or sex, and these perceptions are directly associated with discriminatory actions. Thus, there is a cautionary message for organizational environments and society, considering the urgent need to suppress all forms of discrimination.

Regarding the other instruments used, the dimension that obtained the highest mean in the CAAS was CO (4.25). It suggests that most students held positive beliefs regarding the possibility of achieving their goals, their competencies, and ability to overcome challenges. This result may be associated with self-efficacy (Bandura, 1978; Lent, Brown, \& Hackett, 1994), in which students consider they have well-developed skills such as being efficient, having problem-solving skills, or being able to overcome obstacles. Hence, in this case, the confidence dimension reflects the individuals' self-efficacy toward diverse aspects of their careers (being efficient and careful, diligent, able to learn new tasks, etc.) Hence, these students show confidence in decision-making and in being able to carry out tasks to advance their careers.

Regarding the remaining scales, the PES presented an overall mean of 3.94, showing that students believe they have the skills necessary to work within their fields and that these skills facilitate obtaining a job. According to Bowling, Eschleman and Wang (2010), these perceptions, which refer to their career achievements, are essential because they show that they have a positive attitude toward work. Vianen et al. (2019) also reinforce that employability is an essential assessment when considering career achievements obtained up to the current time. 
The CSS obtained the lowest mean (3.16), revealing that the participants were neither satisfied nor dissatisfied with their careers. One of the most influential factors for increasing the mean was the level of satisfaction with the development of skills, possibly associated with the CAAS' confidence dimension (CO) - which stood out with the highest mean —, and the results regarding perceived employability. In this sense, it appears that the development of skills, being a form of the process of adaptation in the career, reflects in the level of satisfaction of the students, which is in line with Ambiel et al. (2016).

\section{Hypothesis: perceptions of career barriers}

Differences in the perceptions of students distributed in subsamples, according to sex and race, were calculated to verify the first hypothesis (H1). In general, significant differences were found between the perceptions of men and women regarding career barriers. Thus, the test failed to reject H1a. The SD and LO dimensions differed significantly between men and women. Note that female students obtained higher scores in all the IPBC dimensions.

These results are consistent with other studies comparing men's and women's perceptions regarding career barriers (Cardoso, 2009; Faria et al., 2008; LipshitsBraziler \& Tatar, 2012) and reinforce the differences between sexes reported by IBGE (2020) regarding the Brazilian job market. It is also worth noting that the concept of the career barrier itself originated from the difficulties found by women to advance their careers (Cardoso, 2009).

Next, the differences between the perceptions of Caucasian and mixed-race/Afro-Brazilian individuals regarding career barriers were assessed. Note that mixedrace and Afro-Brazilian students compose a single group due to an imbalance in the sample in terms of this demographic variable; a minimum of 118 AfroBrazilians would be needed to create a third subsample. The differences in the perceptions of these two subgroups were statistically significant. Specifically, in the ED and LO dimensions, the Caucasian group and mixed-race and Afro-Brazilian group obtained statistically significant different means. Note that the second subgroup (mixedrace and Afro-Brazilian individuals) scored higher in all the inventory's dimensions.

Therefore, the test failed to reject H1b. In this sense, we infer that sociodemographic characteristics affect an individual's perception of career barriers. These results are in line with Lipshits-Braziler and Tatar (2012), that is, perceptions of career barriers vary according to individual characteristics, including race. Additionally, empirical studies report that Afro-Brazilian individuals perceive career barriers more intensively than their counterparts (Kim \& O’Brien, 2018).

\section{Hypotheses: barriers, adaptability, employability, and satisfaction}

As proposed in $\mathrm{H} 2$ and $\mathrm{H} 3$, perceptions of career outcomes are influenced by one's perception of career barriers. The indicators found between the variables suggest a negative influence, which reinforces the theory proposed by Bullock-Yowell et al. (2011), London (2014) and Silva and Andrade (2016). However, these do not confirm that perceptions of carrier barriers significantly predict employability beliefs and career satisfaction. Hence, $\mathrm{H} 2$ and $\mathrm{H} 3$ were rejected.

These results also show the importance of further studies considering other implicit psychological dimensions with the potential to influence an individual's perceptions concerning career barriers, employability, and satisfaction. An example would be self-efficacy, which is inserted in a career social-cognitive perspective (Brown \& Lent, 2019; Lent et al., 1994) and has been found to influence perceptions regarding career barriers.

For the sake of clarification: hypothetically, an individual perceives many barriers that hinder his/ her advancement in the profession; however, is highly confident and holds strong beliefs regarding his/her self-efficacy. That is, s/he believes in his/her efficiency to perform tasks, solve problems, and develop skills, among others. Hence, this individual plans and works continually to advance in his/her career. Thus, when professional goals are achieved, this individual's beliefs concerning employability and career satisfaction will likely be impacted. Therefore, an individual may perceive many career barriers but still hold favorable perceptions regarding career outcomes.

Cardoso and Moreira (2009), present evidence of this hypothetical situation. The authors suggest that individuals with significant career investments tend to plan more frequently, and thus, more frequently perceive career barriers. This perception, however, does not necessarily result in a perception of low efficacy or poor confidence. Another possible explanation for perceived barriers not influencing one's perception of employability or career satisfaction is that difficulties are perceived as belonging to the economic, political, or social context; that is, these aspects are distant from one's context, not directly influencing one's careers. 
Regarding $\mathrm{H} 4$ and $\mathrm{H} 5$, the results were significant and show that adaptability predicts employability and career satisfaction, i.e., the test failed to reject these hypotheses. Adaptability proves to be relevant because it concerns the individuals' ability to continually adapt to situations (Johnston, 2016; Savickas, 1997), which favors life in general, and more specifically, one's career. The coefficients show that the more an individual develops adaptability skills, the more likely s/he will perceive career outcomes positively.

Recent studies are in line with these findings. For instance, Silva (2016) shows that adaptability facilitates positive perceptions of employability and career satisfaction. The author explains that the continuous development of skills helps workers keep their jobs, favoring positive outcomes at work (such as recognition and promotions), and consequently, increases one's career satisfaction. Ambiel et al. (2016) also reinforce the importance of the relationship between adaptability and career satisfaction, stating that one's satisfaction with the program chosen reflects an individual's level of adaptation toward the career chosen.

Therefore, the results failed to reject H6. In this sense, the greater the advancement promoted by challenging experiences at work and the development of core competencies, abilities, and skills to win and maintain a position, the more likely individuals will perceive they have a successful career, as proposed by Lo Presti and Pluviano (2016) and Vianen et al. (2019). It is interesting to highlight one last connection. According to Vasconcellos, Borges-Andrade, Porto and Fonseca (2016) - currently, the career model most frequently reported is the protean career (Hall, 2004), and one of its theoretical premises is that an individual's employability perception favors career success (Hall, 2004).

Finally, perceptions of career barriers and adaptability explained $40 \%$ of employability, considered a significant effect in studies (Cohen, 1988). As shown by the coefficient of determination $\left(\mathrm{R}^{2}\right)$ of $21 \%$, perceptions of career barriers, adaptability, and employability partially explain career satisfaction. This moderate effect (Cohen, 1988) can be explained by other potential elements influencing young individuals' career satisfaction. The literature reports examples such as feelings toward one's career project (Silva \& Andrade, 2016) and life satisfaction (Bowling, Eschleman, \& Wang, 2010).

\section{CONCLUSIONS}

This study addressed a phenomenon of great relevancefor people in general — career, and also considered one of the main stages of successfully developing a career: obtaining a college degree. The objective was to verify the influence of perceived career barriers and adaptability on employability and career satisfaction among senior undergraduate students attending a Business Administration program. Unexpectedly, perceived barriers did not predict employability or satisfaction. Adaptability, however, appeared as a significant predictor of both. Thus, this study's objective was achieved.

An analysis of contextual barriers to career stands out in terms of this study's scientific contributions. The first hypothesis results show that social and demographic characteristics are potential indicators that can support improved understanding of these barriers. Perceived contextual barriers did not affect perceptions of career outcomes, which involved developing skills and competencies, professional recognition, and success, among others. These career outcomes refer to perceived employability and level of satisfaction. Thus, this study improves understanding regarding contextual career barriers such as lack of support, discrimination, and restricted opportunities in theoretical terms. The conclusion is that these perceptions did not directly affect perceptions of career outcomes, while a perception that the environment imposes many barriers does not necessarily lead to less confidence or lower satisfaction.

The results also reinforce evidence that the continued development of skills to advance professionally and in life positively influences an individual's perceptions regarding his/her general ability for work (employability) and to attain career success. These findings have been previously reported, and this study specifically provides a practical contribution, reinforcing the importance of promoting career adaptability among students in times of career transition, as is the case of the senior students addressed in this study. When HEIs promote skills such as concern, control, curiosity, and confidence among students, these tend to have more favorable perceptions of employability, career success, and satisfaction.

This study's limitations include the fact that the theoretical model was restricted in terms of the constructs predicted by perceptions of career barriers. Other limitations concern the sample characteristics, such as the prevalence of evening programs, private HEIs, and Caucasian students. Thus, future studies are needed to seek an improved understanding of different sociodemographic groups' perceptions regarding career barriers. Models that integrate variables with the potential to influence associations between perceptions of career barriers, employability, and career satisfaction, such as self-efficacy and life satisfaction, are also relevant. 


\section{REFERENCES}

Ambiel, R., Hernández, D., \& Martins, G. (2016). Relaçōes entre adaptabilidade de carreira e vivências acadêmicas no ensino superior. Psicología desde el Caribe, 33(2), 158-168. http://dx.doi.org/10.14482/psdc.33.2.7071

Audibert, A., \& Teixeira, M. A. P. (2015). Escala de adaptabilidade de carreira: Evidências de validade em universitários brasileiros. Revista Brasileira de Orientação Profissional, 16(1), 83-93. Retrieved from http://www.redalyc.org/articulo.oa?id=203041069009

Bandura, A. (1978). Self-efficacy: Toward a unifying theory of behavioral change. Advances in Behaviour Research and Therapy, 1(4), 139-161. https://doi.org/10.1016/0146-6402(78)90002-4

Barbosa Filho, F. H. (2017). A crise econômica de 2014/2017. Estudos Avançados, 31(89), 51-60. http://dx.doi.org/10.1590/s0103-40142017.31890006

Bowling, N. A., Eschleman, K. J., \& Wang, Q. (2010). A metaanalytic examination of the relationship between job satisfaction and subjective well-being. Journal of Occupational and Organizational Psychology, 83(4), 915934. https://doi.org/10.1348/096317909X478557

Brown, S. D., \& Lent, R. W. (2019). A social cognitive view of career development and guidance. In J. A. Athanasou, \& H. N. Perera (Eds.), International handbook of career guidance (Vol. 2, Chap. 7, pp. 147-166). Cham: Springer.

Bullock-Yowell, E., Peterson, G. W., Reardon, R. C., Leierer, S. J., \& Reed, C. A. (2011). Relationships among career and life stress, negative career thoughts, and career decision state: A cognitive information processing perspective. The Career Development Quarterly, 59(4), 302-314. https://doi.org/10.1002/j.2161-0045.2011.tb00071.x

Cardoso, P. (2009). Inventário de percepção de barreiras da carreira (1 ed.). Évora: Departamento de Psicologia da Universidade de Évora. Retrieved from http://hdl.handle.net/10174/2517

Cardoso, P., \& Moreira, J. M. (2009). Self-efficacy beliefs and the relation between career planning and perception of barriers. International Journal for Educational and Vocational Guidance, 9(3), 177. https://doi.org/10.1007/s10775-009-9163-2

Cohen, J. (1988). Statistical power analysis for the behavioral sciences (2 ed). Abingdon, UK: Routledge.

Cozby, P. C. (2003). Métodos de pesquisa em ciências do comportamento (Cap. 7, pp. 141-170). São Paulo: Atlas.

Dahling, J. J., Melloy, R., \& Thompson, M. N. (2013). Financial strain and regional unemployment as barriers to job search self-efficacy: A test of social cognitive career theory. Journal of Counseling Psychology, 60(2), 210-218. https://doi.org/10.1037/a0031492

DeVos, A., DeHauw, S., \&Vander Heijden, B. I. (2011).Competency development and career success: The mediating role of employability. Journal of Vocational Behavior, 79(2), 438447. https://doi.org/10.1016/j.jvb.2011.05.010
Di Fabio, A. (2019). From career development to career management: A positive prevention perspective. In J. A. Athanasou, \& H. N. Perera (Eds.), International handbook of career guidance (Vol. 2, Chap. 10, pp. 209-239). Cham: Springer.

Dunn, T. J., Baguley, T., \& Brunsden, V. (2014). From alpha to omega: A practical solution to the pervasive problem of internal consistency estimation. British JournalofPsychology, 105(3), 399-412. https://doi.org/10.1111/bjop.12046

Faria, L. C., Taveira, M. C., \& Saavedra, L. M. (2008). Exploração e decisão de carreira numa transição escolar: Diferenças individuais. Revista Brasileira de Orientação Profissional, 9(2), 17-30. Retrieved from http://www.redalyc.org/articulo.oa?id=203014920004

Gamboa, V., Paixão, O., \& Palma, A. I. (2014). Adaptabilidade de carreira e autoeficácia na transição para o trabalho: $\mathrm{O}$ papel da empregabilidade percebida-estudo com estudantes do ensino superior. Revista Portuguesa de Pedagogia, (48-2), 133-156. https://doi.org/10.14195/1647-8614 48-2 7

Greenhaus, J. H., Parasuraman, S., \& Wormley, W. M. (1990). Effects of race on organizational experiences, job performance evaluations, and career outcomes. The Academy of Management Journal, 33(1), 64-86. https://doi.org/10.5465/256352

Hair, J. F., Black, W. C., Babin, B. J., Anderson, R. E., \& Tatham, R. L. (2009). Análise multivariada de dados. Porto Alegre: Bookman.

Hall, D. T. (2004). The protean career: A quarter-century journey. Journal of Vocational Behavior, 65(1), 1-13. https://doi.org/10.1016/j.jvb.2003.10.006

Heijde, C., \& Van Der Heijden, B. (2006). A competence-based and multidimensional operationalization and measurement of employability. Human Resource Management, 45(3), 449 476. https://doi.org/10.1002/hrm.20119

Instituto Brasileiro de Geografia e Estatística. (2017). Pesquisa nacional por amostra de domicílios contínua: Algumas características da força de trabalho por cor ou raça. IBGE. Retrieved from ftp://ftp.ibge.gov. br/Trabalho e Rendimento/Pesquisa Nacional por Amostra de Domicilios continua/Trimestral/ Caracteristicas_da_forca_de_trabalho_por_cor_ou_raca/ Algumas caracteristicas da forca de trabalho por cor ou raca 201604 trimestre.pdf

Instituto Brasileiro de Geografia e Estatística. (2020). Pesquisa nacional por amostra de domicílios contínua: Terceiro trimestre de 2020. IBGE. Retrieved from https:// biblioteca.ibge.gov.br/visualizacao/periodicos/2421/ pnact 2020 3tri.pdf

Instituto Nacional de Estudos e Pesquisas Educacionais Anísio Teixeira. (2017). Indicadores de qualidade da educação superior 2015. INEP. Retrieved from http:// download.inep.gov.br/educacao superior/indicadores/ legislacao/2017/apresentacao_indicadores_de_qualidade da educacao superior2015.pdf 
Johnston, C. S. (2016). A systematic review of the career adaptability literature and future outlook. Journal of Career Assessment, 26(1), 3-30. https://doi.org/10.1177/1069072716679921

Kim, Y. H., \& O’Brien, K. M. (2018). Assessing women's career barriers across racial/ethnic groups: The perception of barriers scale. Journal of Counseling Psychology, 65(2), 226238. https://doi.org/10.1037/cou0000251

Kuijpers, M., Schyns, B., \& Scheerens, J. (2006). Career competencies for career success. The Career Development Quarterly, 55(2), 168-178. https://doi.org/10.1002/j.2161-0045.2006.tb00011.x

Ladeira, M., Oliveira, M., Melo-Silva, L., \& Taveira, M. (2019). Adaptabilidade de carreira e empregabilidade na transiçẫo universidade-trabalho: Mediação das respostas adaptativas. Psico-USF, 24(3), 583-595. http://dx.doi.org/10.1590/1413-82712019240314

Lent, R. W., \& Brown, S. D. (2013). Social cognitive model of career self-management: Toward a unifying view of adaptive career behavior across the life span. Journal of Counseling Psychology, 60(4), 557-568. https://doi.org/10.1037/a0033446

Lent, R. W., Brown, S. D., \& Hackett, G. (1994). Toward a unifying social cognitive theory of career and academic interest, choice, and performance. Journal of Vocational Behavior, 45(1), 79-122. https://doi.org/10.1006/jvbe.1994.1027

Lent, R. W., Brown, S. D., \& Hackett, G. (2000). Contextual supports and barriers to career choice: A social cognitive analysis. Journal of Counseling Psychology, 47(1), 36-49. https://doi.org/10.1037/0022-0167.47.1.36

Lipshits-Braziler, Y., \& Tatar, M. (2012). Perceived career barriers and coping among youth in Israel: Ethnic and gender differences. Journal of Vocational Behavior, 80(2), 545554. https://doi.org/10.1016/j.jvb.2011.08.010

Lo Presti, A., \& Pluviano, S. (2016). Looking for a route in turbulent waters: Employability as a compass for career success. Organizational Psychology Review, 6(2), 192-211. https://doi.org/10.1177/2041386615589398

London, M. (2014). Career barriers: How people experience, overcome, and avoid failure. New York: Psychology Press.

Magalhães, M., \& Bendassolli, P. (2013). Desenvolvimento de carreiras nas organizaçôes. In: L. O. Borges, L. Mourão (Eds.), O trabalho e as organizaçôes: Atuaçöes a partir da psicologia. Porto Alegre: Artmed.

Melo, M. R. (2018). Barreiras de carreira, adaptabilidade $e$ satisfação: Percepçôes de alunos formandos em Administração em Instituiçôes de Educação Superior (Master's thesis). Universidade Federal do Espírito Santo, Vitória, Espírito Santo, Brazil.

Melo, M. R., Martins-Silva, P., \& Andrade, A. (2020). Inventário de percepçãodebarreiras decarreira:Estudocom universitários. Revista Brasileira de Orientação Profissional, 21(1), 67-80. https://dx.doi.org/10.26707/1984-7270/2020v21n107

Oreiro, J. L. (2017). A grande recessão brasileira: Diagnóstico e uma agendadepolíticaeconômica. EstudosAvançados,31(89),7588. https://doi.org/10.1590/s0103-40142017.31890009
Perera, H. N., \& Athanasou, J. A. (2019). Introduction: An international handbook of career guidance. In J. A. Athanasou, H. N. Perera (Eds.), International handbook of career guidance (Vol. 2, Chap. 1, pp. 1-22). Cham: Springer.

Pinho, E., Kilimnik, Z., \& Andrade, D. (2015). A influência da estrutura matricial no comprometimento com a carreira em comparaçấo com a estrutura tradicional: Um estudo de caso na EMATER-MG. REGE - Revista de Gestão, 22(2), 223-239. https://doi.org/10.5700/rege560

Praskova, A., Creed, P. A., \& Hood, M. (2015). Self-regulatory processes mediating between career calling and perceived employability and life satisfaction in emerging adults. Journal of Career Development, 42(2), 86-101. https://doi.org/10.1177/0894845314541517

Ristoff, D. (2016). Democratização do campus: Impacto dos programas de inclusão sobre o perfil da graduação. Cadernos do GEA (Grupo Estratégico de Análise da Educação Superior no Brasil), 9, 5-62. Retrieved from http://flacso. org.br/?publication=caderno-gea-n9-democratizacao-docampus-impacto-dos-programas-de-inclusao-sobre-operfil-da-graduacao

Santos, A., \& Gimenez, D. (2015). Inserção dos jovens no mercado de trabalho. Estudos Avançados, 29(85), 153-168. http://dx.doi.org/10.1590/S0103-40142015008500011

Savickas, M. L. (1997). Career adaptability: An integrative construct for life-span, life-space theory. The Career Development Quarterly, 45(3), 247-259. https://doi.org/10.1002/j.2161-0045.1997.tb00469.x

Savickas, M. L. (2013). The theory and practice of career construction. In S. D. Brown \& R. W. Lent (Eds.), Career development and counselling: Putting theory and research to work (2. Ed., pp. 147-183). Hoboken: Wiley.

Savickas, M. L. (2016). Reflection and reflexivity during lifedesign interventions: Comments on career construction counseling. Journal of Vocational Behavior, 97, 84-89. https://doi.org/10.1016/j.jvb.2016.09.001

Savickas, M. L., \& Porfeli, E. J. (2012). Career adapt-abilities scale: Construction, reliability, and measurement equivalence across 13 countries. Journal of Vocational Behavior, 80(3), 661-673. https://doi.org/10.1016/j.jvb.2012.01.011

Silva, M. Z. (2016). Pensamentos negativos de carreira e aspectos psicológicos relacionados à satisfaçáo com os resultados alcançados na vida e na carreira. (Master's thesis). Universidade Federal do Espírito Santo, Vitória, Espírito Santo, Brazil.

Silva, M. Z., \& Andrade, A. L. (2016). Avaliando pensamentos negativos sobre a carreira: $O$ desenvolvimento de uma medida (EPNC). Revista Brasileira de Orientação Profissional, 17(2), 175-187. Retrieved from http://www.redalyc.org/articulo.oa?id=203051246006

Swanson, J., Daniels, K., \& Tokar, D. (1996). Assessing perceptions of career-related barriers: The career barriers inventory. Journal of Career Assessment, 4(2), 219-244. https://doi.org/10.1177/106907279600400207 
Trizano-Hermosilla, I., \& Alvarado, J. M. (2016). Best alternatives to cronbach's alpha reliability in realistic conditions: Congeneric and asymmetrical measurements. Frontiers in Psychology, 7(769). https://doi.org/10.3389/fpsyg.2016.00769

Urbanaviciute, I., Pociute, B., Kairys, A., \& Liniauskaite, A. (2016). Perceived career barriers and vocational outcomes among university undergraduates: Exploring mediation and moderation effects. Journal of Vocational Behavior, 92, 12-21. https://doi.org/10.1016/j.jvb.2015.11.001
Vasconcellos, V. C., Borges-Andrade, J. E., Porto, J. B., \& Fonseca, A. M. D. O. (2016). Carreira nas organizaçóes: Revisão da produção brasileira no âmbito do microcomportamento organizacional. Revista Psicologia Organizaçóes e Trabalho, 16(1), 73-87. https://doi.org/10.17652/rpot/2016.1.375

Vianen, A., Pater, I., \& Preenen, P. (2019). Career success: Employability and the quality of work experiences. In J. A. Athanasou, \& H. N. Perera (Eds.), International handbook of career guidance (Vol. 2, Chap. 11, pp. 241-262). Cham: Springer. 


\section{Authorship}

\section{Mariana Ramos de Melo*}

Universidade Federal do Espírito Santo, Programa de PósGraduação em Administração

Av. Fernando Ferrari, nº 514, Goiabeiras, 29060-220, Vitória, ES, Brazil.

E-mail address: mariramos.melo@gmail.com

(1) https://orcid.org/0000-0001-7826-6050

\section{Priscilla de Oliveira Martins-Silva}

Universidade Federal do Espírito Santo, Programa de PósGraduação em Administração

Av. Fernando Ferrari, no 514, Goiabeiras, 29060-220, Vitória, ES, Brazil.

E-mail address: priscillamartinssilva@gmail.com

(1) https://orcid.org/0000-0002-2922-6607

\section{Alexsandro Luiz de Andrade}

Universidade Federal do Espírito Santo, Programa de PósGraduaçáo em Psicologia

Av. Fernando Ferrari, no 514, Goiabeiras, 29060-220, Vitória, ES, Brazil.

E-mail address: alexsandro.deandrade@yahoo.com

(1) https://orcid.org/0000-0003-4953-0363

\section{Ralf Luis de Moura}

Universidade Federal do Espírito Santo, Programa de PósGraduação em Administração

Av. Fernando Ferrari, no 514, Goiabeiras, 29060-220, Vitória, ES, Brazil.

E-mail address: ralfmoura@gmail.com

(1) https://orcid.org/0000-0002-0170-4056

* Corresponding Author

\section{Funding}

The authors inform that the present work was carried out with the support of the Coordination for the Improvement of Higher Education Personnel (CAPES) - Brazil through the Master's scholarship. The authors would like to thank CAPES for the financial support.

\section{Conflict of Interests}

The authors have stated that there is no conflict of interest.

\section{Copyrights}

RAC owns the copyright to this content.

\section{Authors' Contributions}

$1^{\text {st }}$ author: conceptualization (equal); data curation (lead); formal analysis (lead); funding acquisition (lead); investigation (lead); methodology (lead); project administration (lead); writing - original draft (lead); writing - review \& editing (lead).

$2^{\text {nd }}$ author: conceptualization (equal); data curation (support); formal analysis (support); methodology (support); project administration (support); supervision (lead); writing - review \& editing (support).

$3^{\text {rd }}$ author: conceptualization (support); data curation (support); formal analysis (support); methodology (support); supervision (support); writing - review \& editing (support). $4^{\text {th }}$ author: data curation (support); formal analysis (support); methodology (support); writing - review \& editing (support).

\section{Plagiarism Check}

The RAC maintains the practice of submitting all documents approved for publication to the plagiarism check, using specific tools, e.g.: iThenticate.

\section{Peer Review Method}

This content was evaluated using the double-blind peer review process. The disclosure of the reviewers' information on the first page, as well as the Peer Review Report, is made only after concluding the evaluation process, and with the voluntary consent of the respective reviewers and authors.

\section{Data Availability}

All data and materials have been made publicly available through the Harvard Dataverse platform and can be accessed at:

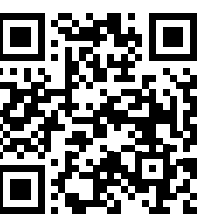

Mariana Ramos de Melo; Priscilla de Oliveira Martins-Silva; Alexsandro Luiz de Andrade; Ralf Luis de Moura, 2021, "Replication Data for: "Barriers, Adaptability, Employability, and Satisfaction: Career Perceptions of Graduates in Administration"", Harvard Dataverse, V1. https://doi.org/10.7910/DVN/UWSMUO

RAC encourages data sharing but, in compliance with ethical principles, it does not demand the disclosure of any means of identifying research subjects, preserving the privacy of research subjects. The practice of open data is to enable the reproducibility of results, and to ensure the unrestricted transparency of the results of the published research, without requiring the identity of research subjects. 